\title{
Impact of spatial data resolution on simulated catchment water balances and model performance of the multi-scale TOPLATS model
}

\section{H. Bormann}

University of Oldenburg, Department of biology and environmental sciences, Uhlhornsweg 84, 26111 Oldenburg, Germany

Received: 30 August 2005 - Published in Hydrol. Earth Syst. Sci. Discuss.: 10 October 2005

Revised: 16 January 2006 - Accepted: 18 January 2006 - Published: 3 March 2006

\begin{abstract}
This paper analyses the effect of spatial input data resolution on the simulated water balances and flow components using the multi-scale hydrological model TOPLATS. A data set of $25 \mathrm{~m}$ resolution of the central German Dill catchment $\left(693 \mathrm{~km}^{2}\right)$ is used for investigation. After an aggregation of digital elevation model, soil map and land use classification to $50 \mathrm{~m}, 75 \mathrm{~m}, 100 \mathrm{~m}, 150 \mathrm{~m}, 200 \mathrm{~m}, 300 \mathrm{~m}, 500 \mathrm{~m}$, $1000 \mathrm{~m}$ and $2000 \mathrm{~m}$, water balances and water flow components are calculated for the entire Dill catchment as well as for 3 subcatchments without any recalibration. The study shows that model performance measures and simulated water balances almost remain constant for most of the aggregation steps for all investigated catchments. Slight differences in the simulated water balances and statistical quality measures occur for single catchments at the resolution of $50 \mathrm{~m}$ to $500 \mathrm{~m}$ (e.g. 0-3\% for annual stream flow), significant differences at the resolution of $1000 \mathrm{~m}$ and $2000 \mathrm{~m}$ (e.g. $2-12 \%$ for annual stream flow). These differences can be explained by the fact that the statistics of certain input data (land use data in particular as well as soil physical characteristics) changes significantly at these spatial resolutions. The impact of smoothing the relief by aggregation occurs continuously but is barely reflected by the simulation results. To study the effect of aggregation of land use data in detail, in addition to current land use the effect of aggregation on the water balance calculations based on three different land use scenarios is investigated. Land use scenarios were available aiming on economic optimisation of agricultural and forestry practices at different field sizes ( $0.5 \mathrm{ha}, 1.5 \mathrm{ha}$ and $5.0 \mathrm{ha}$ ). The changes in water balance terms, induced by aggregation of the land use scenarios, are comparable with respect to catchment water balances compared to the current land use. A correlation analysis between statistics of input data and simulated annual water fluxes only in some cases reveals systematically
\end{abstract}

Correspondence to: H. Bormann

(helge.bormann@uni-oldenburg.de) high correlation coefficients for all investigated catchments and data sets (e.g. actual evapotranspiration is correlated to land use, surface runoff generation is correlated to soil properties). Predominantly the correlation between catchment properties (e.g. topographic index, transmissivity, land use) and simulated water flows varies from catchment to catchment. Catchment specific properties determine correlations between properties and fluxes, but do not influence the effect of data aggregation. This study indicates that an aggregation of input data for the calculation of regional water balances using TOPLATS type models leads to significant errors from a resolution exceeding $500 \mathrm{~m}$. Correlating statistics of input data and simulation results indicates that a meaningful aggregation of data should in the first instance aim on preserving the areal fractions of land use classes.

\section{Introduction}

Many recent environmental problems such as non-point source pollution and habitat degradation are addressed at basin scale (e.g. the "Water Framework Directive" of the European Union, EU-WFD, 2000) and require spatially explicit analyses and predictions. Especially future predictions have to be based on model applications to simulate future conditions of ecosystems in catchments and the effects of environmental change. As the water flow is essential for transport of nutrients and pollutants as well as the development of habitats, distributed modelling of water flows and related state variables is a pre-requisite to contribute to the solution of these environmental problems.

Spatially distributed modelling of regional water fluxes and water balances requires a number of huge spatial data sets. At least spatial information on topography (digital elevation model), soils and vegetation is needed. Thereby the higher the resolution of these data is the better the landscape is represented by the data base (Kuo et al., 1999). Spatial

Published by Copernicus GmbH on behalf of the European Geosciences Union. 
patterns can be represented more in detail and small scale fluxes can be considered by the models.

But a higher spatial and temporal resolution of data and model application does not always lead to a better representation of the water fluxes for a given catchment. This depends on the spatiotemporal variability and the spatial distribution of catchment properties. Varying spatial resolution can also have effects on response times of catchments. And spatial discretisation may influence model sensitivity at different scales by varying consideration of climatological variability. For example Andreassian et al. (2001) found that imperfect rainfall knowledge can reduce the consistency of catchment model parameters.

Despite a better representation of the landscape highly resolved data often contain redundant information and lead to an increase in required storage capacity and computer time (Omer et al., 2003). And, of course, highly resolved data are not always available for every catchment of interest. Therefore new initiatives search for new ways to better represent the catchment water fluxes in poor data situations. One well known example is the PUB initiative (prediction of ungauged basins) of the International Association of Hydrological Sciences (Sivapalan et al., 2003).

Furthermore the benefit of a detailed data base strongly depends on the model type applied and on the target of a study. Focusing on annual water balances of large scale catchments, for instance, does not require diurnal input data at micro-scale resolution. And lumped, conceptual models do not exploit highly resolved data in the same way as spatially distributed and process based models do. Therefore the decision, which data resolution to be sufficient for a distinct model application, has to be made again for every case study. As it is very time-consuming and costly to perform this analysis, unfortunately it is not made for each study. Based on experience of the user and data availability, the appropriate data resolution is chosen for a given scale and a given target. But the impact of spatial resolution on simulation results mostly is not investigated.

A few studies have examined the effect of grid size of topographic input data on catchment simulations using TOPMODEL (Beven et al., 1995). Quinn et al. (1991), Moore et al. (1993), Zhang and Montgomery (1994), Bruneau et al. (1995) and Wolock and Price (1994) looked at how grid size affected the computed topographic characteristics, wetness index and outflow. In general, they found that higher resolved grids gave better results. Kuo et al. (1999) applied a variable sources area model to grid sizes from 10 to $600 \mathrm{~m}$ and revealed an increasing misrepresentation of the curvature of the landscape with increasing grid size while soil properties and land use distribution were not affected. Effects themselves depended on the wetness of the time periods considered. Thieken et al. (1999) examined the effect of differently sized elevation data sets on catchment characteristics and calculated hydrographs of single events. They found that these data sets with a resolution between 10 and
$50 \mathrm{~m}$ strongly diverged in landscape representation. Furthermore these differences in topographic and geomorphologic features could be used to explain differences in the runoff simulation of single events. The effect on long-term water balances was not investigated. Farajalla and Vieux (1995) showed that the aggregation of spatial input data led to a decrease in entropy of soil hydraulic parameters between $200 \mathrm{~m}$ and $600 \mathrm{~m}$ grid size and to a significant decrease for grid sizes over $1000 \mathrm{~m}$. To overcome the problem of information loss with increasing grid size Beven (1995) suggests the consideration of subgrid variability by spatial distribution functions of properties or parameters. This only works if high resolution data sets are available. Model concepts which are based on Hydrological Response Units (HRUs) instead of grid cells are faced with the same problem. For that reason the effect of a decreasing number of HRUs on the simulation results was investigated by various authors, too (e.g. Chen and Mackay, 2004; Lahmer et al., 2000; Bormann et al., 1999). They found that a minimum number of HRUs is required to represent the variability in catchment properties while further increasing of computational units does not improve the simulation results significantly. Boiij (2005) compared three spatial resolutions comparing the conceptual HBV-model to the Meuse river (1, 15, and 118 subcatchments). The model results after individual calibration at all resolutions showed that all models reproduced well the average and the extremes, while increasing the resolution slightly improved the model results. Skøien and Blöschl (2003) analysed characteristic space scales more in general by performing a variogramm analysis on hydrological fluxes (precipitation, runoff) and state variables (groundwater tables, soil moisture). They found that the variance of stream flow increases faster with decreasing catchment size than with the inverse of catchment area which can be interpreted as an indicator for spatial organisation. Information on spatial organisation disappears with increased data aggregation. But they also found characteristic space scales in the order of $8 \mathrm{~km}$ to $60 \mathrm{~km}$ which is much larger than the model resolution investigated in this study. So these characteristic space scales should not limit the results obtained in this study.

Although it is well reported in literature that data resolution can have a significant impact on the simulation results, model results of different models often are compared and evaluated without taking the basic data resolution into account. Therefore this study elaborates in detail, which effect the chosen data and model resolution can have on model performance and simulated water balances considering all spatial data sets required. Based on a detailed spatial data set ( $25 \mathrm{~m}$ resolution) of the meso-scale Dill catchment $\left(693 \mathrm{~km}^{2}\right)$ in central Germany a systematic data aggregation (from $25 \mathrm{~m}$ to $2000 \mathrm{~m}$ ) and subsequent model application is carried out to investigate the limitations of data aggregation and model applicability in case of the TOPLATS model (Famiglietti and Wood, 1994a). The study aims on the calculation of water balances, therefore effects of aggregation on response times 
Table 1. Main processes and equations of the TOPLATS model.

\begin{tabular}{|c|c|c|}
\hline Model part & Process & Approach \\
\hline \multirow[t]{9}{*}{ Local SVATs } & Interception & Storage approach: storage capacity is proportional to leaf area index \\
\hline & Potential evapotranspiration (PET) & Penman Monteith equation (plant specific PET) (Monteith, 1965) \\
\hline & Actual evapotranspiration & $\begin{array}{l}\text { Reduction of PET by actual soil moisture status (alternative: solving } \\
\text { energy balance equation) }\end{array}$ \\
\hline & Infiltration & $\begin{array}{l}\text { Infiltration capacity after Milly (1986) (depending on soil properties and } \\
\text { soil water status) }\end{array}$ \\
\hline & Infiltration excess runoff & Difference between rainfall rate and infiltration capacity \\
\hline & Saturation excess runoff & $\begin{array}{l}\text { Contributing areas derived from TOPMODEL; approach based on the } \\
\text { soils topographic index }\end{array}$ \\
\hline & Percolation & Gravity driven drainage \\
\hline & Capillary rise & $\begin{array}{l}\text { Capillary rise from local water table based on Gardner (1958) using } \\
\text { Brooks and Corey parameters }\end{array}$ \\
\hline & Lower boundary condition & Top of capillary fringe (= depth of local water table) \\
\hline TOPMODEL & $\begin{array}{l}\text { Spatial distribution of water table depths } \\
\text { base flow }\end{array}$ & $\begin{array}{l}\text { Soils-topographic index (Sivapalan et al., 1987) } \\
\text { Exponential decay function; maximum base flow is base flow at basin } \\
\text { saturation }\end{array}$ \\
\hline
\end{tabular}

do not play a major role. The potential influence of grid size dependent rainfall variability was excluded by using the same weather inputs for the simulations on different grid sizes. The influence of the aggregation of the spatial input data sets such as land use, topography and soils is additionally investigated by analysing correlation coefficients between input data and simulation results. To further explore the effect of differently structured land cover three land use scenarios are aggregated and studied supplementary.

The motivation for this study arose from a model comparison initiative (LUCHEM initiative, "Assessing the impact of land use change on hydrology by ensemble modelling", initiated by the working group on "Resources Management of the University of Gießen, Germany") where different catchment models were compared despite differences in process representation, spatial conceptualisation (grid, HRUs) and spatial resolution in a relatively tight range $(25 \mathrm{~m}-200 \mathrm{~m})$. There the question of the influence of grid size on simulation results arose.

\section{Material and methods}

\subsection{Toplats model}

The TOPLATS model ("TOPMODEL based atmosphere transfer scheme"; Famiglietti and Wood, 1994a; Peter-Lidard et al., 1997) is a multi-scale model to simulate local to regional scale catchment water fluxes. It combines a "soil vegetation atmosphere transfer scheme" (SVAT) to represent local scale vertical water fluxes with the catchment scale TOPMODEL approach (Beven et al., 1995) to laterally redistribute the water within a catchment.
TOPLATS is a grid based and time continuous model. The vertical water fluxes of the grid cells are calculated by the local SVATs (Fig. 1). Catchment scale vertical water fluxes are obtained by aggregation of local water fluxes. There is no lateral interaction between the local SVATs accounted for by the model. But based on the soils topographic index of the TOPMODEL approach (Beven et al., 1995), a lateral redistribution of water is realized by adaptation of the local groundwater levels which are used as lower boundary conditions of the local SVATs. Finally, based flow is generated from the integration of local saturated subsurface fluxes along the channel network. A routing routine is not integrated in the model. The basic hydrological processes and their representation in the TOPLATS model are summarized in Table 1.

In vertical direction the soil is divided in 2 layers (root zone and transmission zone). According to Sivapalan et al. (1987) it is assumed that saturated conductivity exponentially decreases with depth. The percolation is calculated using an approximation for gravity driven drainage, and capillary rise is calculated based on the approach of Gardner (1958), both approaches using the Brooks and Corey parameterisation of soil retention characteristics (Brooks and Corey, 1964). Based on soil texture and porosity soil parameters are derived using the pedotransfer-function of Rawls and Brakensiek (1985). Plant growth is not directly simulated by TOPLATS, but the seasonal development of plant properties is described by monthly updating the plant parameter sets consisting of e.g. leaf area index, plant height and stomatal resistance. Plant parameters were taken from the PlaPaDa data base (Breuer et al., 2003). The digital elevation model serves as basic data set for the calculation of the topographic wetness index (Beven et al., 1995), which is used for 
Table 2. Scale relevant characteristics of TOPLATS model applications in literature. "Parameter distribution function" refers to the statistical mode of TOPLATS considering spatial variability of basin properties by a parameter distribution function (Famiglietti and Wood, 1994a). The statistical mode was not used in this study.

\begin{tabular}{|c|c|c|c|}
\hline Paper & $\begin{array}{l}\text { Catchment } \\
\text { size }\end{array}$ & $\begin{array}{l}\text { Grid } \\
\text { size }\end{array}$ & $\begin{array}{l}\text { Simulation } \\
\text { period }\end{array}$ \\
\hline Famiglietti and Wood (1994b) & $\begin{array}{l}\text { Site } \\
12 \mathrm{~km}^{2} \\
225 \mathrm{~km}^{2}\end{array}$ & $\begin{array}{l}- \\
30 \mathrm{~m} \\
\text { parameter distribution function }\end{array}$ & $\begin{array}{l}\text { Days } \\
\text { Days } \\
3 \text { weeks }\end{array}$ \\
\hline Peters-Lidard et al. (1997) & $225 \mathrm{~km}^{2}$ & parameter distribution function & 5 months \\
\hline Pauwels and Wood (1999b) & Site & - & 1 year \\
\hline Endreny et al. (2000) & $532 \mathrm{~km}^{2}$ & $\begin{array}{l}30 \mathrm{~m} \\
60 \text { index values }\end{array}$ & $\begin{array}{l}12 \text { days } \\
10 \text { years }\end{array}$ \\
\hline Crow and Wood (2002) & $575000 \mathrm{~km}^{2}$ & $\begin{array}{l}1 \mathrm{~km} \\
\text { parameter distribution functions for } 314 \\
\text { subcatchents }\end{array}$ & $\begin{array}{l}4 \text { months } \\
39 \text { months }\end{array}$ \\
\hline Pauwels et al. (2002) & $114 \mathrm{~km}^{2}$ & $30 \mathrm{~m}$ & 4 years \\
\hline Seuffert et al. (2002) & $2000 \mathrm{~km}^{2}$ & $1 \mathrm{~km}$ & 3 years \\
\hline Bormann and Diekkrüger (2003) & $3133 \mathrm{~km}^{2}$ & $100 \mathrm{~m}$ & 1 year \\
\hline $\begin{array}{l}\text { Giertz (2004) and } \\
\text { Bormann et al. (2005) }\end{array}$ & $30 \mathrm{~km}^{2}$ & $20 \mathrm{~m}$ & 1 year \\
\hline Crow et al. (2005) & $6378 \mathrm{~km}^{2}$ & $90 \mathrm{~m}$ & 1 month \\
\hline
\end{tabular}

calculation of the soils-topographic index (see Table 1) additionally accounting for local differences in transmissivity (Sivapalan et al., 1987). For further details about the model the reader is referred to Famiglietti and Wood (1994a) and Peters-Lidard et al. (1997).

The TOPLATS model has been successfully applied in several studies at different scales (Table 2) and in different climate regions around the world. Famiglietti and Wood (1994b) applied TOPLATS to the tallgrass prairie in the United States. They applied TOPLATS to single sites and a small catchment $\left(12 \mathrm{~km}^{2}\right)$ and simulated diurnal variations of water fluxes up to a couple of weeks to be able to compare simulations to evapotranspiration measurements. Pauwels and Wood (1999a, b) extended the TOPLATS model to the application in high latitudes in Canada. They also focused on small scale simulations (sites) but simulated water and energy fluxes for whole seasons.

Recent TOPLATS related publications more and more focus on regional applications and on the integration of remotely sensed data to improve the simulations. Endreny et al. (2000) examined the effects of the errors induced by the use of digital elevation models derived from SPOT data and compared the simulation results to those based on standard data sets (USGS 7.5-min data set). Analysing the effects of the accuracy of the digital elevation model on simulated water fluxes he implicitly also investigated the aggregation effect. It can be assumed that accuracy of the digital elevation model decreases with increasing grid size as the surface is smoothed. Seuffert et al. (2002) coupled TOPLATS to an atmospheric model ("Lokal-Modell" of the German Me- teorological Service) and applied the model to the regional scale Sieg catchment (about $2000 \mathrm{~km}^{2}$ ) in Western Germany. Pauwels et al. (2002) investigated the possibility to improve TOPLATS based simulation by the use of ERS derived soil moisture values at the catchment scale. A similar study was performed by Crow and Wood (2002) in the Red Arkansas basin who explored the benefit of coarse-scale soil moisture images for macro-scale model applications of TOPLATS $\left(575000 \mathrm{~km}^{2}\right)$. And Crow et al. (2005) also examined the possibility to upscale field-scale soil moisture measurements by means of distributed land surface modelling. In the context of this study they also expanded the soil module within TOPLATS considering vertical soil heterogeneity. Finally Bormann and Diekkrüger (2003), Giertz (2004) and Bormann et al. (2005) applied TOPLATS to the subhumid tropics of West Africa to simulate seasonal dynamics stream flow and soil moisture. They found that TOPLATS reproduced spatial patterns of soil moisture and seasonal dynamics in stream flow on the local scale driven by local mapping campaigns. Based on poor data neither on local nor on regional scale TOPLATS could reproduce the hydrological behaviour of the catchments as physiographic variability was not covered by the data. Therefore applicability of TOPLATS in the subhumid tropics seems to be limited by input data availability.

Recapitulating TOPLATS has successfully been applied to a wide range of temporal and spatial scales in different climate regions (Table 2). Analysing the scale relevant characteristics of the cited model applications it can be observed that model applications range from site scale to macroscale, 


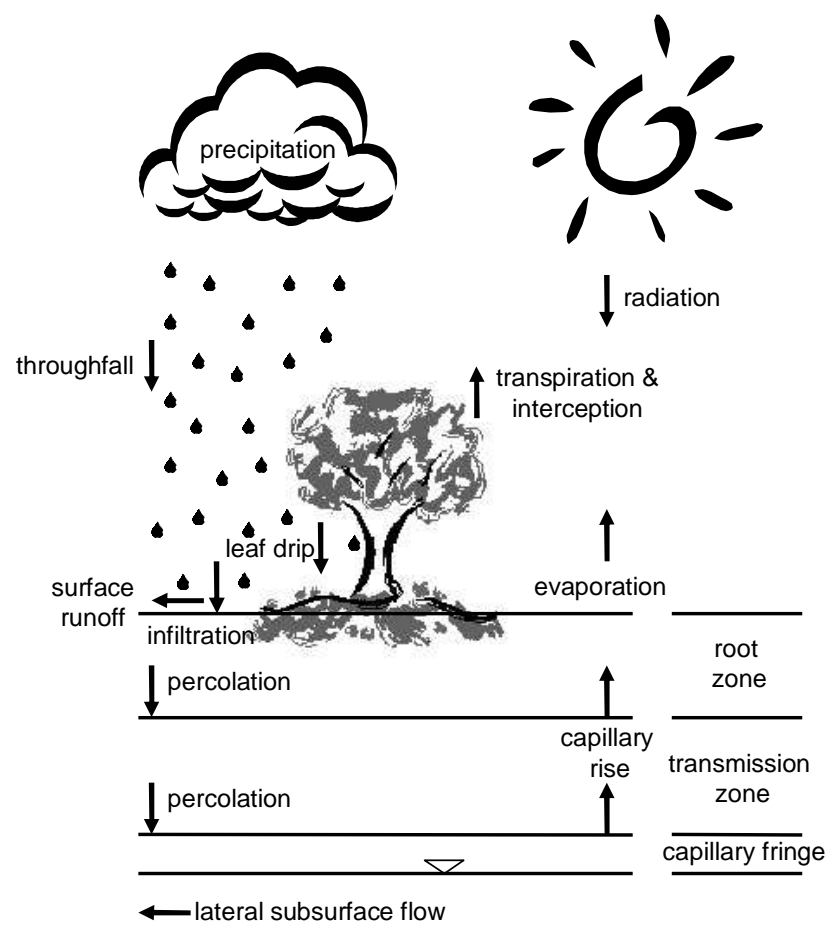

Fig. 1. Hydrological processes of the local SVATs represented by the TOPLATS model (modified after Famiglietti and Wood, 1994a).

and grid sizes range from $20 \mathrm{~m}$ to $1 \mathrm{~km}$. On the small catchment scale applications are run with small grid sizes while for large catchments also larger grid cells are used. This implicates constraints in data availability and in computational effort and underpins the necessity to investigate the effect of aggregation and increasing grid size on model results.

\subsection{Catchment characteristics and available data sets of the Dill basin}

The Dill catchment $\left(693 \mathrm{~km}^{2}\right)$ is located in central Germany and belongs to the Lahn-Dill low mountainous region. It is the target catchment of the SFB 299 ("Land use options for peripheral regions") of the University of Gießen (Germany). Stream gauging stations exist for three sub-catchments (Upper Dill $\left(63 \mathrm{~km}^{2}\right)$, Dietzhölze $\left(81 \mathrm{~km}^{2}\right)$ and Aar $\left.\left(134 \mathrm{~km}^{2}\right)\right)$ as well as for the entire Dill catchment at Asslar $\left(693 \mathrm{~km}^{2}\right.$, Fig. 2).

The typical small scale topography ranges between $155 \mathrm{~m}$ and $674 \mathrm{~m}$ above sea level. The mean steepness of the slopes is approximately $14 \%$. Mean annual rainfall ranges between $700 \mathrm{~mm}$ to $1100 \mathrm{~mm}$ depending on the location within the catchment and the corresponding elevation. Low precipitation areas show summer-dominated precipitation and high precipitation areas winter-dominated precipitation regimes. Average annual mean temperature is about $8^{\circ} \mathrm{C}$.

Soil parent material of the Lahn-Dill mountains is mainly argillaceous schist, greywacke, diabase, sandstone, quartzite,

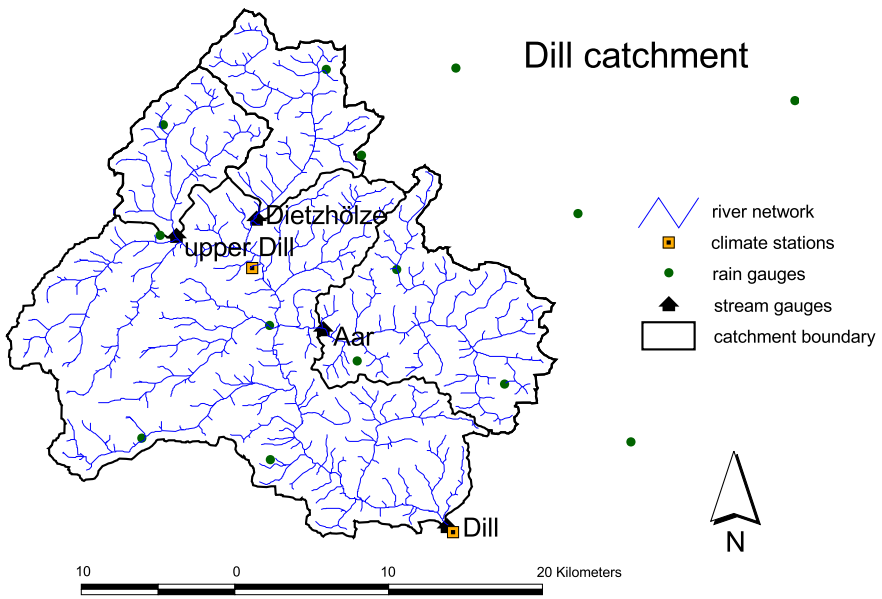

Fig. 2. Subcatchments (upper Dill, Dietzhölze, Aar), rain and stream gauges in the Dill catchment $\left(693 \mathrm{~km}^{2}\right)$ in central Germany.

and basalt which developed during the Devon and Lower Carbon. During the Pleistocene periglacial processes have strongly influenced the soil parent material. Therefore periglacial layers strongly influenced by the underlying geologic substrate are the main soil parent material of the catchment. Due to the heterogeneous nature of these periglacial layers, the pattern of soil types is complex. Main soil types are shallow cambisols, planosols derived from luvisols under hydromorphic conditions, and gleysols in groundwater influenced valleys.

Typical for most of the catchment area is a hard rock aquifer. Pore aquifers only exist in quaternary deposits such as river terraces or hillslope debris. Based on empirical relations the portion of baseflow contribution to discharge can be estimated to an amount of 9-16\%. Most of the discharge of the Dill river is delivered through interflow. The contribution of surface runoff is estimated to be less than $10 \%$.

Current land cover of the Dill area is dominated by forest. $29.5 \%$ of the catchment is covered by deciduous forest, $24.9 \%$ by coniferous forest. $20.5 \%$ of the catchment area is used for grassland and $6.5 \%$ agricultural crops. A portion of about $9 \%$ of the area is fallow land, and another $9 \%$ is covered by urban area. Obviously the Dill catchment is a peripheral region dominated by extensive agriculture and forestry. Thanks to the SFB 299 of the University of Gießen a detailed data base is available for the whole Dill basin at $25 \mathrm{~m}$ resolution. Spatial data sets and time series (rain gauges, climate stations and stream gauges, for location of the stations see Fig. 2) used in this study are summarised in Table 3.

\subsection{Data aggregation}

As the impact of increasing information loss on the calculation of regional scale water fluxes was to be investigated by this study, the available data set of $25 \mathrm{~m}$ resolution was 


\begin{tabular}{|l|l|}
\hline 1 & 2 \\
\hline 2 & 4 \\
\hline
\end{tabular}

\begin{tabular}{|l|l|}
\hline 1 & 2 \\
\hline 2 & 4 \\
\hline
\end{tabular}

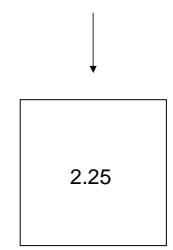

a) Simple average

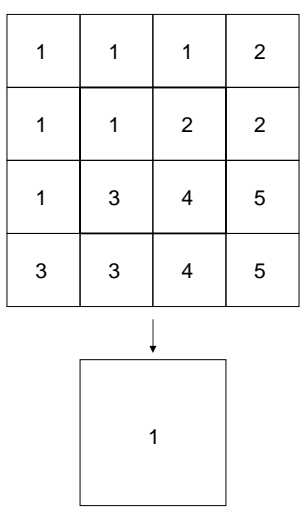
c) Majority including
surrounding pixels
Fig. 3. Algorithms for systematic aggregation of spatial data sets: simple average (a) for DEM aggregation, majority (b) for aggregation of land use and soils, consideration of the surrounding pixels if there is no unambiguous majority (c).

aggregated stepwise to create grid based data sets of increasing grid size: $50 \mathrm{~m}, 75 \mathrm{~m}, 100 \mathrm{~m}, 150 \mathrm{~m}, 200 \mathrm{~m}, 300 \mathrm{~m}$, $500 \mathrm{~m}, 1 \mathrm{~km}$, and $2 \mathrm{~km}$. Therefore the spatial data sets (soil map, DEM, land use classification, land use scenarios) were systematically aggregated applying standard aggregation methods provided by standard GIS software.

The aggregation of the DEM was carried out by calculating the arithmetic averages of the pixels to be aggregated. Concerning soils and land use the data sets were aggregated with respect to the majority of the pixels to be aggregated. The most frequent value was allocated to the aggregated pixel. If there was no unambiguous majority the surrounding pixels were included into the allocation (Fig. 3). Applying these algorithms, the DEM is smoothened by averaging, and the total area of small homogenous areas of classified data (soils, land use) decreases as small areas often disappear at the expense of large homogenous areas.

\section{Model application to the Dill catchment}

\subsection{Calibration and validation}

In order to reduce the calibration of the TOPLATS model for application to the Dill basin to a minimum, parameterisation of the TOPLATS model was carried out by deriving or using directly as many parameters as possible from standard data bases. Those parameters have not been touched during the calibration procedure. Thus transferability of the model and the obtained results to other catchments is improved. Calibration could be reduced to an adjustment of plant specific stomatal resistances by a constant factor to meet the longterm water balance and to the calibration of the parameters of the base flow recession curve. During the calibration process, two performance measures were applied. At first, calibration aimed at the annual water balance of the whole Dill catchment to close the water balance of the model, and secondly the model efficiency according to Nash and Suttcliffe (1970) was optimised for daily resolution to reproduce the temporal variability of stream flow focusing on seasonal dynamics and short time variability. Applying these two quality measures, both long-term water balances and seasonal dynamics were covered well. Model calibration for the Dill catchment was carried out on the $50 \mathrm{~m}$ grid due to a limitation in the number of computational units within TOPLATS.

Figure 4 shows the simulation results for the entire Dill catchment $\left(693 \mathrm{~km}^{2}\right)$ compared to the observed values of the stream gauges. Calibration period is from 1983-1989, validation period from 1990-1999. The accuracy of the simulation is satisfactory (quality measures see Table 4) considering that TOPLATS was calibrated only with respect to stomatal resistance and the baseflow recession curve. Quality measures for the validation period are only slightly worse than for the calibration period. While for daily discharges the model efficiency (Nash and Suttliffe, 1970) is of moderate quality ( 0.65 for calibration, 0.61 for validation), the model efficiencies and coefficients of determination increase for longer time intervals (longer than one week) to values greater than 0.8 . The mean bias in discharge between observations and simulations is about $5 \%$ for calibration and $12 \%$ for validation period.

For the simulation of the three subcatchments a recalibration was not carried out except the maximum baseflow parameter (baseflow at basin saturation). The simulation results for the Dietzhölze $\left(81 \mathrm{~km}^{2}\right)$ and the upper Dill $\left(63 \mathrm{~km}^{2}\right)$ are quite good while the results for the Aar catchment $\left(134 \mathrm{~km}^{2}\right)$ are of a moderate quality. Model efficiencies for daily discharges range between 0.59 and 0.73 (calibration period) and between 0.52 and 0.69 (validation period). They increase with increasing time interval to values of 0.76 to 0.85 (weeks) and 0.82 to 0.90 (months). The values of the coefficients of determination $\left(r^{2}=\right.$ squared Pearson correlation coefficient) are slightly higher than the model efficiencies but show the same systematics. Quality measures and water balances for the Dill basin as well as for the three subcatchments are shown in detail in Table 4.

Based on these simulations results it can be stated that TOPLATS can be applied to successfully simulate water balances at regional scale in the low mountain range in temperate climates considering the minimum calibration strategy. Single peak flow events cannot be simulated with a high precision, but long-term water balances can be simulated just as well as seasonal variations of the water fluxes, and dry and wet periods within a season can be covered as well.

\subsection{Model results based on increasing grid sizes}

For all different grid sizes derived from the original data sets $(25 \mathrm{~m}, 50 \mathrm{~m}, 75 \mathrm{~m}, 100 \mathrm{~m}, 150 \mathrm{~m}, 200 \mathrm{~m}, 300 \mathrm{~m}$, $500 \mathrm{~m}, 1 \mathrm{~km}, 2 \mathrm{~km})$ continuous water balance simulations 
Table 3. Spatial data sets and time series available for the Dill catchment; the three land use scenarios only consist of 6 land use classes instead of 7 for current land use as the Proland model (Fohrer et al., 2002) does not differentiate between deciduous and coniferous forest.

\begin{tabular}{|c|c|c|c|}
\hline Domain & Data source/gauge stations & Resolution/classification & Origin of data set \\
\hline \multirow{3}{*}{ Space } & Land use classification & $\begin{array}{l}25 \mathrm{~m} \text { resolution, } 7 \text { classes (deciduous forest, conif- } \\
\text { erous forest, grassland, agricultural crops, fallow } \\
\text { land, open water bodies and urban areas) }\end{array}$ & $\begin{array}{l}\text { Derived from multi-temporal Landsat im- } \\
\text { ages (from } 1994 \text { and 1995) }\end{array}$ \\
\hline & Digital elevation model & 25 m resolution & HLBG (2000) \\
\hline & 3 land use scenarios & $\begin{array}{l}25 \mathrm{~m} \text { resolution; } 6 \text { classes (mixed forest, grassland, } \\
\text { agricultural crops, fallow land, open water bodies } \\
\text { and urban areas) }\end{array}$ & $\begin{array}{l}\text { Land use distribution derived from Proland } \\
\text { model (Fohrer et al., 2002) }\end{array}$ \\
\hline \multirow[t]{3}{*}{ Time } & 2 weather stations & $\begin{array}{l}\text { Daily resolution; 1980-1999; temperature, air hu- } \\
\text { midity, wind speed, solar radiation }\end{array}$ & German Meteorological Service (DWD) \\
\hline & 15 rain gauges & Daily resolution; 1980-1999 & German Meteorological Service (DWD) \\
\hline & 4 stream gauges & Daily resolution; 1980-1999 & HLUG (2005) \\
\hline
\end{tabular}

Table 4. Quality measures for the calibration (cal.) and validation periods (val.) of the four stream gauges within the Dill basin.

\begin{tabular}{|c|c|c|c|c|c|c|}
\hline Quality measure & Cal./Val. & Time interval & Dill & Upper Dill & Dietzhölze & Aar \\
\hline \multirow{2}{*}{$\begin{array}{l}\text { Mean deviation in annual } \\
\text { stream flow }\end{array}$} & Cal. & Annual & $4.7 \%$ & $8.9 \%$ & $6.6 \%$ & $11.4 \%$ \\
\hline & Val. & Annual & $12.0 \%$ & $17.8 \%$ & $7.2 \%$ & $17.6 \%$ \\
\hline \multirow{8}{*}{$\begin{array}{l}\text { Model efficiency } \\
\text { (Nash and Suttcliffe, 1970) }\end{array}$} & \multirow{4}{*}{ Cal. } & Daily & 0.65 & 0.73 & 0.69 & 0.59 \\
\hline & & Weekly & 0.81 & 0.85 & 0.82 & 0.76 \\
\hline & & Monthly & 0.84 & 0.90 & 0.87 & 0.82 \\
\hline & & Annual & 0.90 & 0.80 & 0.86 & 0.78 \\
\hline & \multirow[t]{4}{*}{ Val. } & Daily & 0.61 & 0.69 & 0.69 & 0.52 \\
\hline & & Weekly & 0.79 & 0.84 & 0.83 & 0.77 \\
\hline & & Monthly & 0.82 & 0.88 & 0.87 & 0.82 \\
\hline & & Annual & 0.80 & 0.64 & 0.92 & 0.63 \\
\hline \multirow{8}{*}{$\begin{array}{l}\mathrm{R}^{2} \text { (= Coefficient } \\
\text { of determination) }\end{array}$} & \multirow[t]{4}{*}{ Cal. } & Daily & 0.71 & 0.74 & 0.74 & 0.63 \\
\hline & & Weekly & 0.81 & 0.85 & 0.83 & 0.77 \\
\hline & & Monthly & 0.86 & 0.90 & 0.88 & 0.83 \\
\hline & & Annual & 0.91 & 0.89 & 0.87 & 0.94 \\
\hline & \multirow[t]{4}{*}{ Val. } & Daily & 0.68 & 0.74 & 0.73 & 0.62 \\
\hline & & Weekly & 0.81 & 0.86 & 0.83 & 0.78 \\
\hline & & Monthly & 0.85 & 0.91 & 0.88 & 0.83 \\
\hline & & Annual & 0.78 & 0.78 & 0.91 & 0.66 \\
\hline
\end{tabular}

of 20 years were performed without a recalibration of the TOPLATS model. Model resolution was for every simulation adapted to the input data resolution. TOPLATS was not recalibrated as the model as introduced by Famiglietti and Wood (1994a) assumes that at the SVAT scale vertical fluxes are dominant. They propose to transfer the model to regional scale by aggregation of simulated fluxes and by taking into account lateral processes using the TOPMODEL concept. Aggregating input data and applying the model without re- calibration accommodates these assumptions as vertical water fluxes such as actual evapotranspiration and percolation are hardly influenced by grid size of the local SVAT. If the model results significantly get worse with increasing grid size, then the reason is that input data and TOPMODEL concept do not match anymore. A threshold of reasonable data aggregation is reached. If the model is recalibrated for each aggregation step, then the result may be that the model also works at larger grid cells, but then the model probably works 
(a)

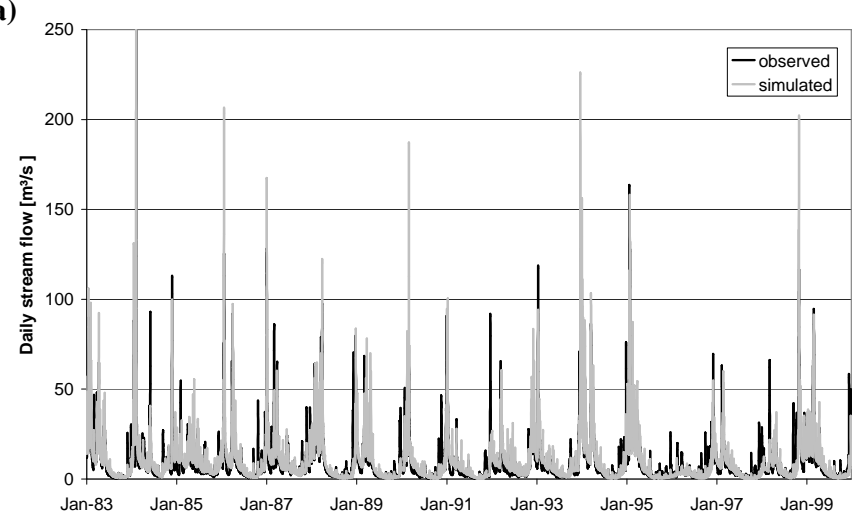

(c)

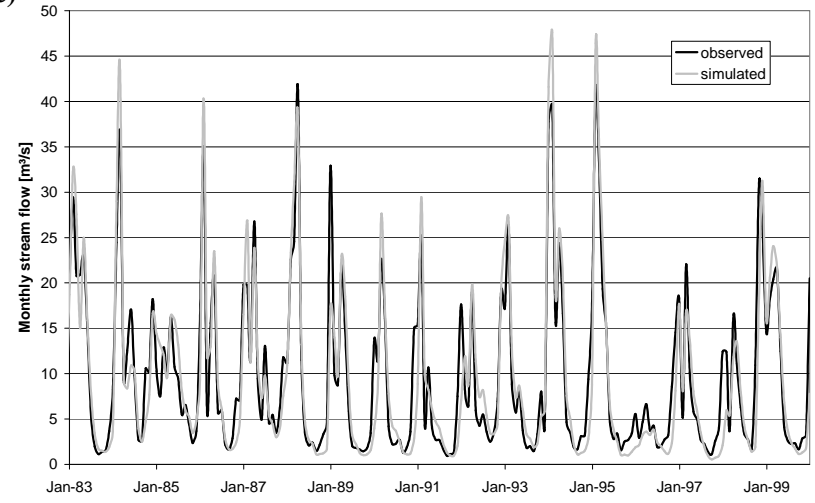

(b)

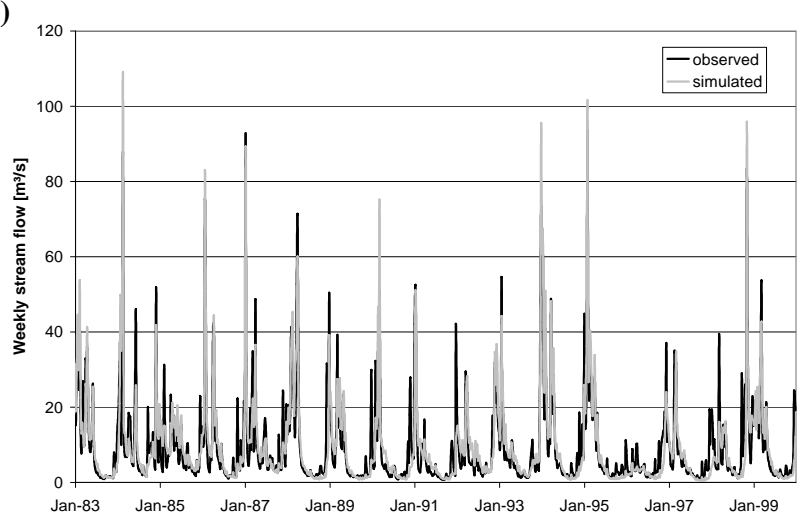

(d)

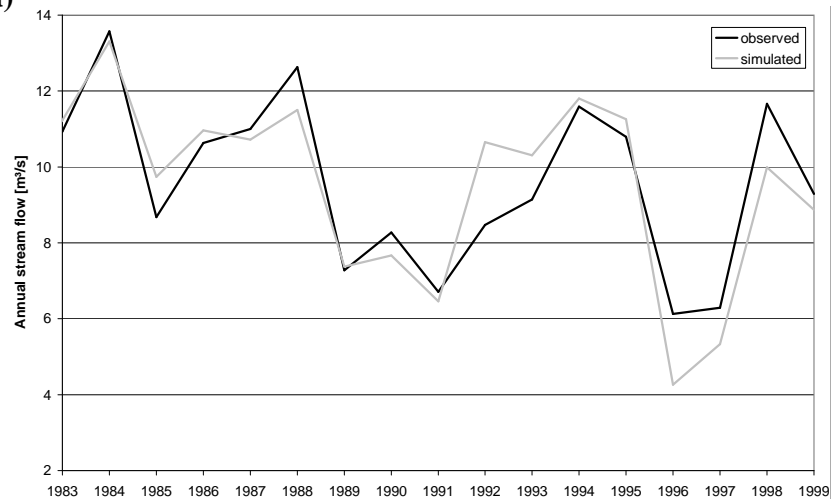

Fig. 4. Hydrographs of the Dill catchment: comparison of observed vs. simulated stream flow in daily (a), weekly (b), monthly (c) and annual (d) resolution.

well for the wrong reason. Although the grid cells are that big that lateral flow processes are relevant, the model calculates good results ignoring the lateral processes. Based on this analysis the model specific minimum data resolution and therefore the minimum simulation effort required for good simulation quality aiming on water balance investigations can be determined.

The computations reveal almost constant simulated annual water balances (Fig. 5) and model efficiencies (Fig. 6) for most of the grid sizes. Up to a grid size of $300 \mathrm{~m}$ the simulated water fluxes remain almost constant except slight differences at individual grid sizes (e.g. at $100 \mathrm{~m}$, which can be explained by differences in land use composition at the $100 \mathrm{~m}$ aggregation level) for individual water flows (e.g. for actual evapotranspiration). At a grid size of $500 \mathrm{~m}$ the differences slightly increase, and from $1000 \mathrm{~m}$ grid size onwards the simulation results get significantly worse. Differences to simulations based on small grid sizes increase. Thereby the results of the calibration period and the validation period again show the same regularity: if the simulation results are good for the calibration period, then also for the validation period good results are obtained. The same observation was made for bad agreement between the model and the measurements. This observation is valid for all investigated (sub-)catchments within the Dill region. Therefore no further separate analysis for calibration and validation periods is required.

This statement concerning grid size dependent simulated water balances is also valid for the model efficiencies calculated from observations and model simulations. The model efficiencies - as expected from the simulated water balances - remain constant up to a threshold value of $300 \mathrm{~m}$ to $500 \mathrm{~m}$ grid size. Model efficiencies for the $1000 \mathrm{~m}$ and the $2000 \mathrm{~m}$ grids are significantly lower. At this scale a significant and systematic decrease of this quality measure is observed (Fig. 6). In addition to the results of the Dill catchment (Figs. 5, 6), Tables 5 and 6 summarise the scale dependent model efficiencies and biases in stream flow for the calibration (1983-1989) and validation period (1990-1999) calculated for all subcatchments within the Dill basin.

To investigate the influence of different land use distributions on the diverging behaviour of simulated water balances for increasing grid sizes above a threshold of between $300 \mathrm{~m}$ and $500 \mathrm{~m}$, three land use scenarios were used for further simulations. For this study not the effect of the scenarios compared to the current state is of interest but again the effect of increasing grid size on the simulated scenario water balances. The scenarios were calculated by the "Proland 
(a)

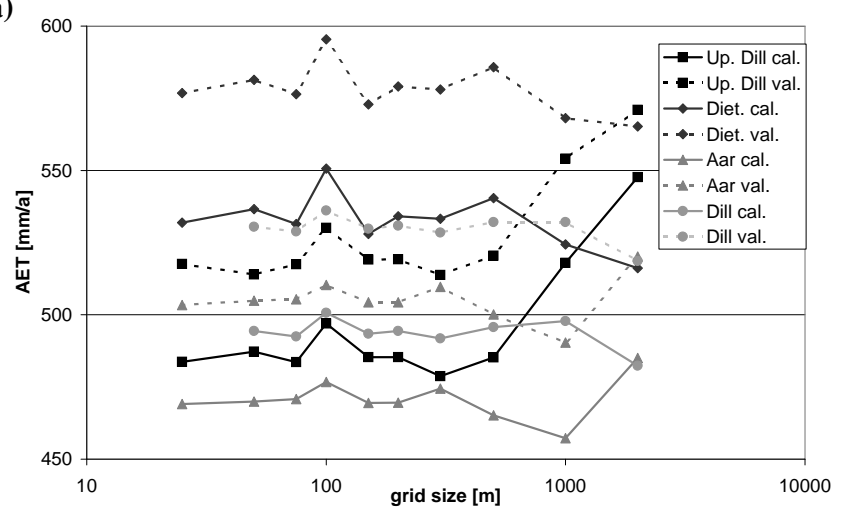

(b)

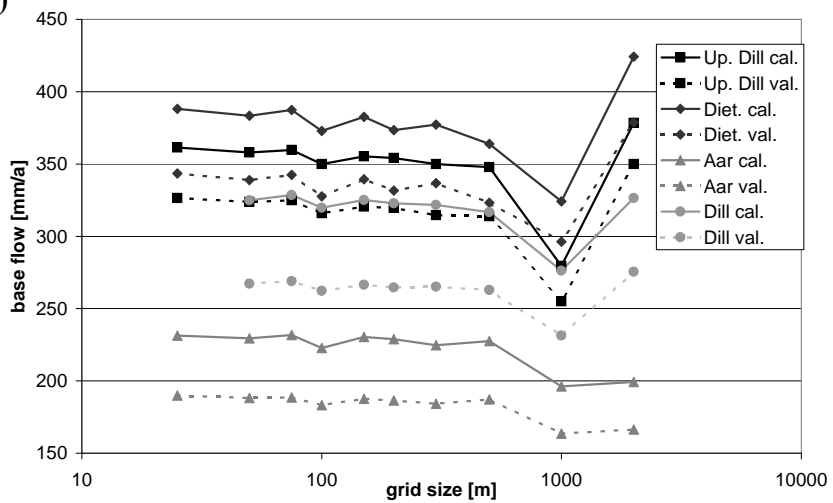

(c)

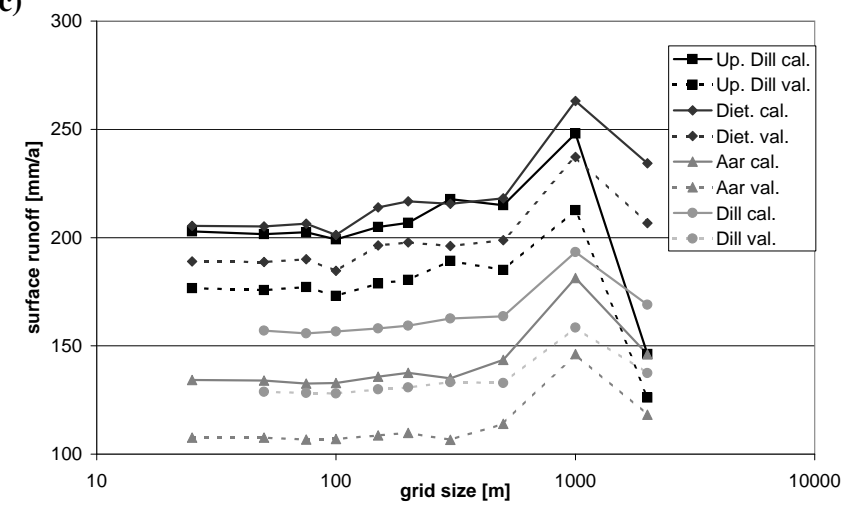

Fig. 5. Grid size dependence of simulated annual water fluxes: actual evapotranspiration (AET) (a), base flow (b) and surface runoff (c) of the Dill basin and its three subcatchments (Up. Dill $=$ Upper Dill, Diet. = Dietzhölze). Calibration periods and validation periods (cal., val.) are analysed separately.

Table 5. Grid size dependent model efficiencies (me) for the four (sub-)catchments of the Dill basin (cal.=calibration period, val.=validation period).

\begin{tabular}{ccccccccc}
\hline Grid size & \multicolumn{2}{c}{ Dill } & \multicolumn{2}{c}{ Upper Dill } & \multicolumn{2}{c}{ Dietzhölze } & \multicolumn{2}{c}{ Aar } \\
& me (cal) & me (val) & me (cal) & me (val) & me (cal) & me (val) & me (cal) & me (val) \\
\hline $25 \mathrm{~m}$ & - & - & 0.73 & 0.69 & 0.70 & 0.70 & 0.58 & 0.46 \\
$50 \mathrm{~m}$ & 0.65 & 0.61 & 0.73 & 0.69 & 0.70 & 0.70 & 0.58 & 0.46 \\
$75 \mathrm{~m}$ & 0.66 & 0.61 & 0.73 & 0.69 & 0.70 & 0.70 & 0.58 & 0.46 \\
$100 \mathrm{~m}$ & 0.65 & 0.61 & 0.72 & 0.68 & 0.69 & 0.69 & 0.57 & 0.46 \\
$150 \mathrm{~m}$ & 0.66 & 0.61 & 0.73 & 0.68 & 0.70 & 0.70 & 0.58 & 0.46 \\
$200 \mathrm{~m}$ & 0.66 & 0.61 & 0.73 & 0.68 & 0.70 & 0.70 & 0.57 & 0.46 \\
$300 \mathrm{~m}$ & 0.65 & 0.61 & 0.73 & 0.69 & 0.69 & 0.69 & 0.57 & 0.46 \\
$500 \mathrm{~m}$ & 0.65 & 0.61 & 0.72 & 0.68 & 0.70 & 0.70 & 0.56 & 0.45 \\
$1000 \mathrm{~m}$ & 0.64 & 0.63 & 0.68 & 0.64 & 0.67 & 0.68 & 0.50 & 0.40 \\
$2000 \mathrm{~m}$ & 0.64 & 0.61 & 0.67 & 0.55 & 0.58 & 0.62 & 0.51 & 0.42 \\
\hline
\end{tabular}

model" (Fohrer et al., 2002) optimising the financial profit of the catchment area based on different minimum field sizes $(0.5,1.5$ and $5.0 \mathrm{ha})$. Land use fractions are summarized in Table 7. So the spatial structures as well as land use composition of the different land use scenarios differ a lot. If the regularity of the results with respect to increase in grid size is the same for all scenarios and the baseline, then the land use distribution does not have a major influence on the structure of the simulation results, and results on data aggregation are transferable to other basins. 
Table 6. Grid size dependent bias of total stream flow (Qt) for the entire simulation period (=bias(Qt), [\%]) for the four (sub-)catchments of the Dill basin.

\begin{tabular}{ccccccccc}
\hline \multirow{2}{*}{ Grid size } & \multicolumn{2}{c}{ Dill Bias (Qt), [\%] } & \multicolumn{2}{c}{ Upper Dill Bias (Qt), [\%] } & \multicolumn{2}{c}{ Dietzhölze Bias (Qt), [\%] } & \multicolumn{3}{c}{ Aar Bias (Qt), [\%] } \\
& Cal. & Val. & Cal. & Val. & Cal. & Val. & Cal. & Val. \\
\hline $25 \mathrm{~m}$ & - & - & 2.7 & 15.2 & 0.6 & 2.7 & 2.0 & 0.3 \\
$50 \mathrm{~m}$ & 0.6 & -0.4 & 1.8 & 14.4 & -0.2 & 1.7 & 1.5 & -0.3 \\
$75 \mathrm{~m}$ & 1.0 & -0.1 & 2.3 & 15.0 & 0.7 & 2.6 & 1.7 & -0.5 \\
$100 \mathrm{~m}$ & 0.6 & -1.8 & -0.1 & 12.1 & -2.6 & -1.2 & 0.0 & -2.1 \\
$150 \mathrm{~m}$ & 0.8 & -0.3 & 1.9 & 14.4 & 1.2 & 3.3 & 2.0 & -0.1 \\
$200 \mathrm{~m}$ & 0.6 & -0.6 & 2.1 & 14.5 & 0.1 & 2.1 & 1.8 & -0.1 \\
$300 \mathrm{~m}$ & 1.0 & 0.2 & 3.3 & 15.4 & 0.5 & 2.7 & 0.4 & -2.0 \\
$500 \mathrm{~m}$ & 0.2 & -0.5 & 2.4 & 41.3 & -1.3 & 0.7 & 2.8 & 2.8 \\
$1000 \mathrm{~m}$ & -2.0 & -2.0 & -3.4 & 7.3 & -3.4 & 3.0 & 2.6 & 2.6 \\
$2000 \mathrm{~m}$ & 3.3 & 3.8 & -4.5 & 9.1 & 11.7 & 13.0 & -1.8 & -1.6 \\
\hline
\end{tabular}

Table 7. Land use composition of the three scenarios based on different field sizes compared to the current land use composition.

\begin{tabular}{ccccccc}
\hline Land use data set & Forest & Pasture & Crops & Fallow & Water & Urban \\
\hline current land use & $54.4 \%$ & $20.5 \%$ & $6.5 \%$ & $9.1 \%$ & $0.3 \%$ & $9.2 \%$ \\
scenario 0.5 ha & $56.0 \%$ & $31.8 \%$ & $2.7 \%$ & - & $0.3 \%$ & $9.2 \%$ \\
scenario 1.5 ha & $45.9 \%$ & $17.5 \%$ & $27.1 \%$ & - & $0.3 \%$ & $9.2 \%$ \\
scenario 5.0 ha & $34.0 \%$ & $20.6 \%$ & $35.9 \%$ & - & $0.3 \%$ & $9.2 \%$ \\
\hline
\end{tabular}

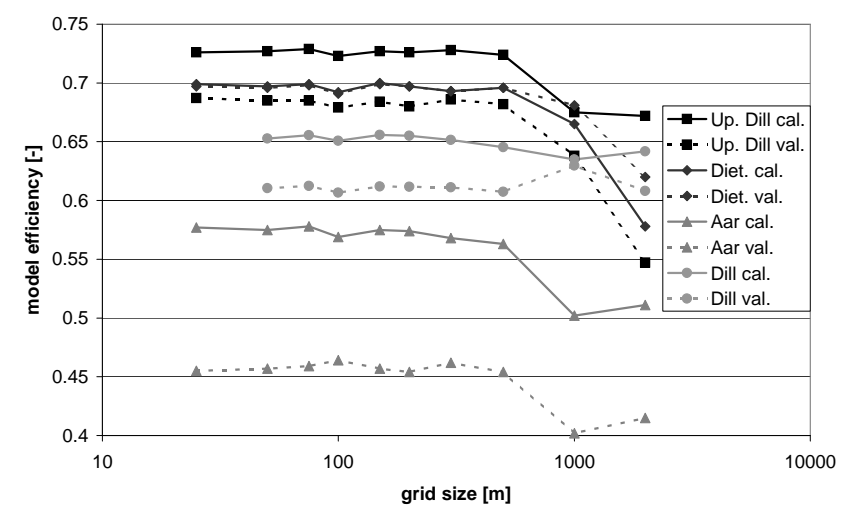

Fig. 6. Dependence of model efficiencies (based on daily simulations) on grid sizes for the Dill basin and its three subcatchments (Up. Dill $=$ Upper Dill, Diet. $=$ Dietzhölze $)$. Calibration periods and validation periods (cal., val.) are analysed separately.

Figure 7 shows as an example the simulation results of the three different, field size dependent scenarios for the upper Dill basin. It is obvious that simulated mean annual water flows show almost no differences up to a grid size of $200 \mathrm{~m}$, show only minor differences up to a grid size of $500 \mathrm{~m}$ and big differences for large grid sizes $(1 \mathrm{~km}, 2 \mathrm{~km})$. These exemplary results on different land use data sets for the upper Dill catchment are very similar to the results of the other three catchments. The land use scenarios therefore show the same systematic reaction on data aggregation as the current land use does. Thus it can be concluded that there is no significant impact of the spatial structure of land use on the regularity of the simulation results based on grid size aggregation.

\section{Correlation between changes and catchment proper- ties}

In order to analyse the influences of the different aggregated data sets on the grid size dependent simulation results a correlation analysis was carried out based on the statistics of catchment properties and annual water balance terms. An analysis of univariate correlations assumes linear correlations between catchment characteristics and water flows. This assumption normally is not justified at local scale as it is clear that interrelations between hydrological processes and basin properties are highly nonlinear. That is one of the main reasons why complex hydrological models are needed to predict water fluxes of catchments with complex structure. Nevertheless local scale non-linear systems often show approximately linear reactions at regional scale (e.g. for actual evapotranspiration and groundwater flow), and changes in catchment wide fluxes often can be simply derived by analysing changes in catchment properties (e.g. evapotranspiration by using plant properties). So the idea in this part of the paper 
(a)

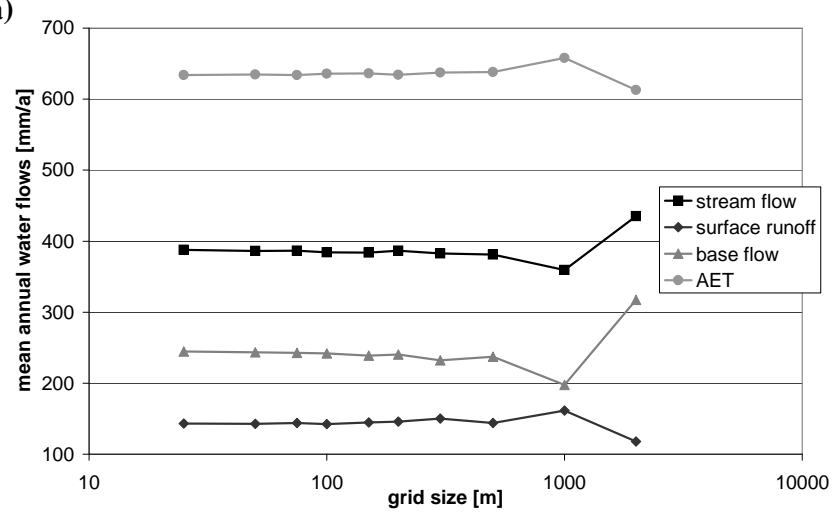

(b)

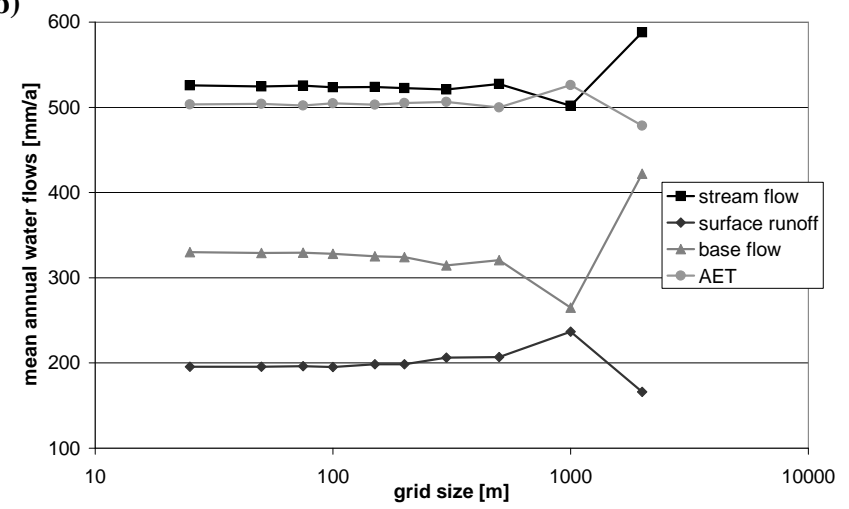

(c)

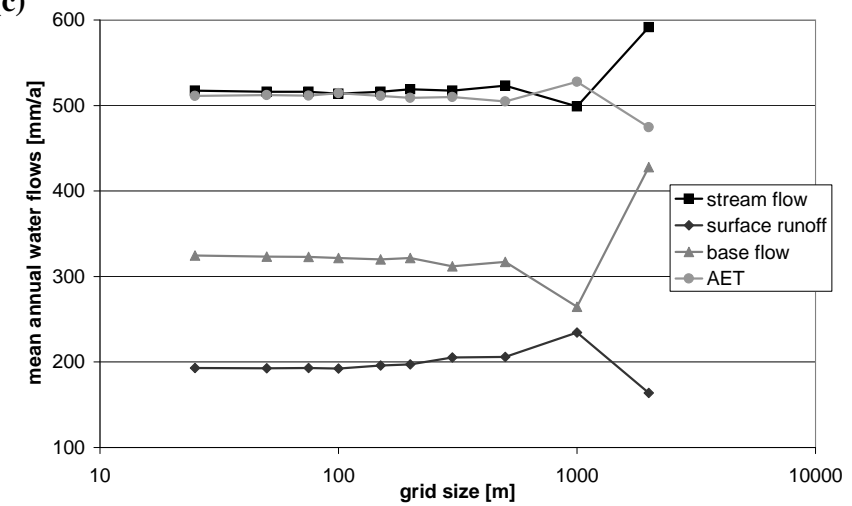

Fig. 7. Grid size dependent simulation results of the three different land use scenarios ( $0.5 \mathrm{ha}=\mathrm{a}), 1.5 \mathrm{ha}=\mathrm{b}), 5 \mathrm{ha}=\mathrm{c}))$ for the upper Dill basin; $\mathrm{AET}=$ actual evapotranspiration.

Table 8. Correlation coefficients (Pearson) between input data (transmissivity, topographic index, land use) and model results (water balances, biases) for the entire Dill catchment; forest $=$ deciduous + coniferous forest; agriculture $=$ crops + pasture.

\begin{tabular}{llllll}
\hline Catchment property & Bias in Stream flow & Stream flow & Surface runoff & Base flow & Actual ET \\
\hline Crops & 0.18 & 0.25 & -0.54 & 0.53 & -0.19 \\
Pasture & -0.57 & -0.63 & 0.39 & -0.60 & 0.62 \\
Fallow & 0.80 & 0.85 & 0.05 & 0.37 & -0.92 \\
Deciduous forest & 0.47 & 0.42 & 0.43 & -0.12 & -0.51 \\
Coniferous forest & -0.81 & -0.78 & -0.17 & -0.25 & 0.79 \\
Urban & -0.46 & -0.51 & -0.63 & 0.24 & 0.74 \\
Open water & 0.92 & 0.89 & -0.31 & 0.66 & -0.76 \\
Forest & -0.78 & -0.81 & 0.34 & -0.64 & 0.70 \\
Agriculture & -0.73 & -0.78 & 0.21 & -0.53 & 0.79 \\
Mean topographic index & -0.14 & -0.12 & 0.98 & -0.80 & -0.15 \\
Standard deviation of topographic index & -0.79 & -0.75 & 0.40 & -0.67 & 0.56 \\
Mean transmissivity & 0.95 & 0.92 & -0.46 & 0.79 & -0.77 \\
Standard deviation of transmissivity & 0.92 & 0.89 & -0.56 & 0.85 & -0.71 \\
\hline
\end{tabular}

is - as nonlinear and multivariate relationships hardly can be analysed for the huge number of computational units - simply trying to quantify "linear" contributions of changes in input data sets to the sensitivity of the whole system. This information later can be used for an analysis of model sensitivity with respect to data aggregation effects.

All spatial input data sets change significantly in statistics during aggregation. Increasing the grid size leads to a 
(a)

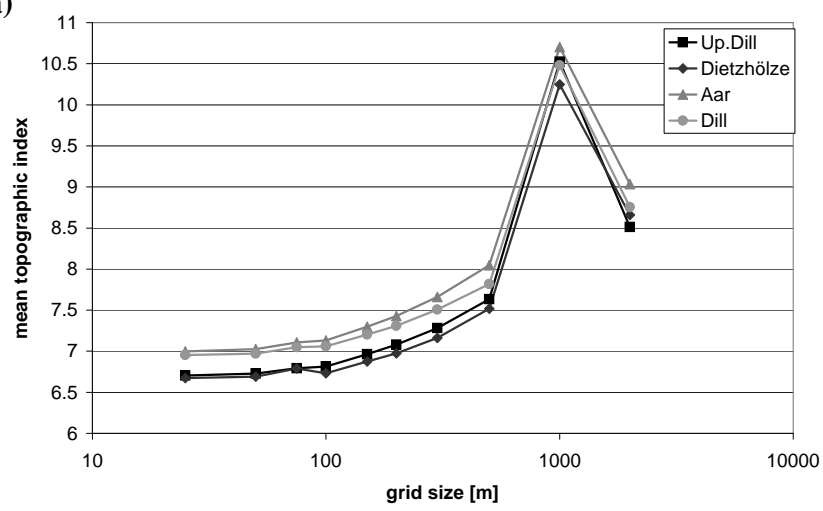

(b)

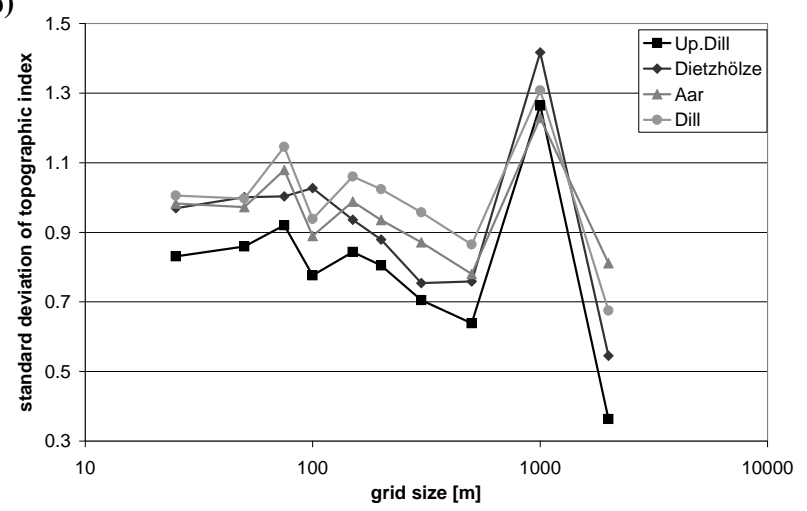

Fig. 8. Grid size dependent statistics of topographic catchment properties of the Dill catchment: mean value (a) and standard deviation (b) of topographic index.

(a)

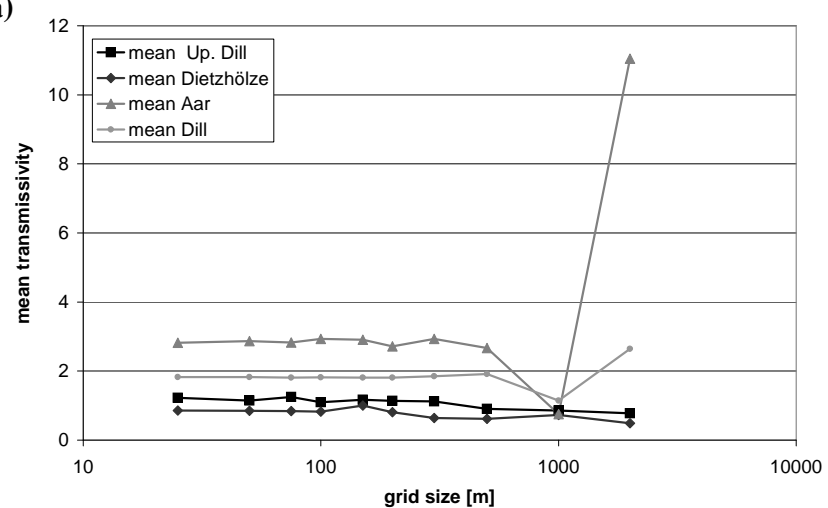

(b)

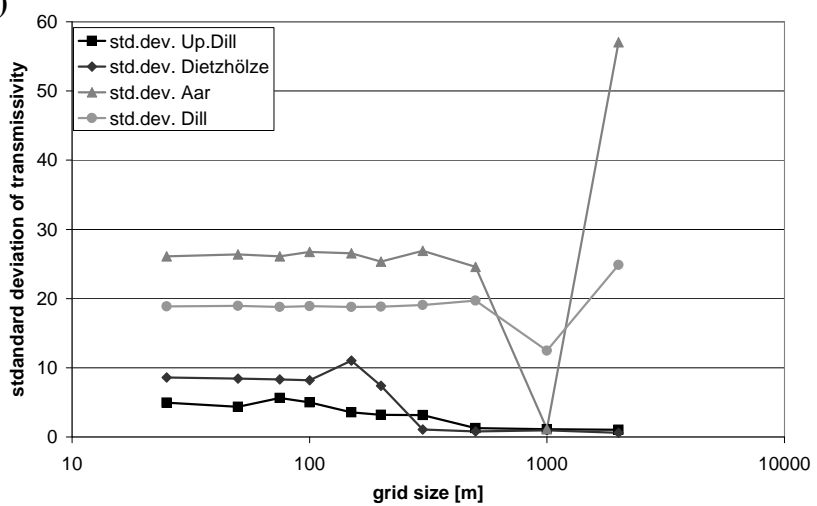

Fig. 9. Grid size dependent statistics of soil hydrological catchment properties of the Dill catchment: mean value (a) and standard deviation (b) of transmissivity.

smoothed surface of elevation and therefore to an increased mean topographic index (as cell size increases and slope in average decreases) and a decreasing standard deviation of the topographic index (Fig. 8). For single aggregation levels extreme values occur (e.g. $1000 \mathrm{~m}$ level for topographic index) while the tendency is the same for all investigated catchments.

The transmissivity of the soils in general is barely affected by aggregation in a systematic way. Single extreme values occurring (Fig. 9) do not show a homogenous tendency for the different catchments. The behaviour strongly depends on local soil hydraulic conditions and soil depths.

The effect of aggregation on the land use fractions is exemplarily shown for the entire Dill basin by Fig. 10. It becomes clear that the aggregation has no major effect up to a cell size of $500 \mathrm{~m}$. Only at the $100 \mathrm{~m}$ level significant deviations for pasture and fallow land occur which was found to have an influence on the simulated water flows and model efficiencies (Figs. 5, 6). For grid sizes lager than $500 \mathrm{~m}$ significant changes in land use fractions can be observed for almost all land use classes. This is due to the fact that large areas grow at the expense of small areas, and grid sizes become larger than the average size of a homogenous area is. The effect of aggregation on land use fractions in the Dill catchment is comparable to the effects in the subcatchments which are summarised in Fig. 11.

To examine the contribution of the different data sources to the grid size dependent effects, a correlation analysis between water balance components and catchment properties was carried out. The correlation coefficients for the entire Dill basin are summarised in Table 8 . From the structure of the simulation results it would first have been expected that land use has a major influence on the simulations. This can be approved by the data. Forest areas are positively correlated to evapotranspiration and negative to stream flow production, while fallow areas and agricultural crops are correlated vice versa. Nevertheless one has to be careful because also spurious correlations appear in the data 
(e.g. contrary correlation coefficients of coniferous and deciduous forest), and coherences between data and simulation results of course cannot be explained by linear correlations only. Nevertheless, water balance terms also show a clear dependence on soil and topographic characteristics. Surface runoff and base flow are highly correlated to the topographic index (surface runoff in a positive, base flow in a negative way), and transmissivity is correlated with base flow (positively) and evapotranspiration (negatively) as well as surface runoff (negatively). To reduce spurious correlations the land use classes "forest" and "agriculture" were built from deciduous and coniferous forest as well as from crops and pasture. Analysing the correlation coefficients of these two merged land use classes several times the correlation coefficient increases for the merged land use class which can be interpreted as increased significance of correlation and elimination of spurious correlation.

Simulation results are related to all spatial data sets, and evaluation of the effect of data aggregation therefore has to consider all data sources. Nevertheless it is worth to mention that predominantly the correlation between catchment properties (e.g. topographic index, transmissivity, land use) and simulated water flows varies from catchment to catchment, in particular at the small scale. Partly this could be expected due to different physiographic characteristics of the subbasins (varying forest cover in the subbasins, different soil properties), but partly the differences cannot be explained by the input data only and result from spurious correlations. One example for spurious correlations is the following: different signs were identified for the correlation between stream flow and deciduous forest $(0.42)$ and coniferous forest $(-0.78)$, respectively, while both classes together show a correlation coefficient of -0.81 which is below the value for coniferous forest. Additionally a correlation analysis between catchment average model parameters (e.g. plant parameters such as leaf area index, stomatal resistance) was performed. But also for catchment average model parameters the subcatchments showed different correlation, and the analysis could not reveal all reasons.

\section{Conclusion: Limitations of model application}

This study indicates that an aggregation of input data for the calculation of regional water balances using TOPLATS type models does not lead to significant errors up to a grid size of $300 \mathrm{~m}$. Between a grid size of 300 and $500 \mathrm{~m}$ a slightly to partly significant information loss leads to affected simulation results, while applying a grid size of $1 \mathrm{~km}$ and more causes significant errors in the computed water balance. If algorithms are integrated in a model taking into account subgrid variability further investigations are required.

The results of this study indicate that a meaningful aggregation of data should in the first instance aim on preserving the areal fractions of land use classes, because land use is the

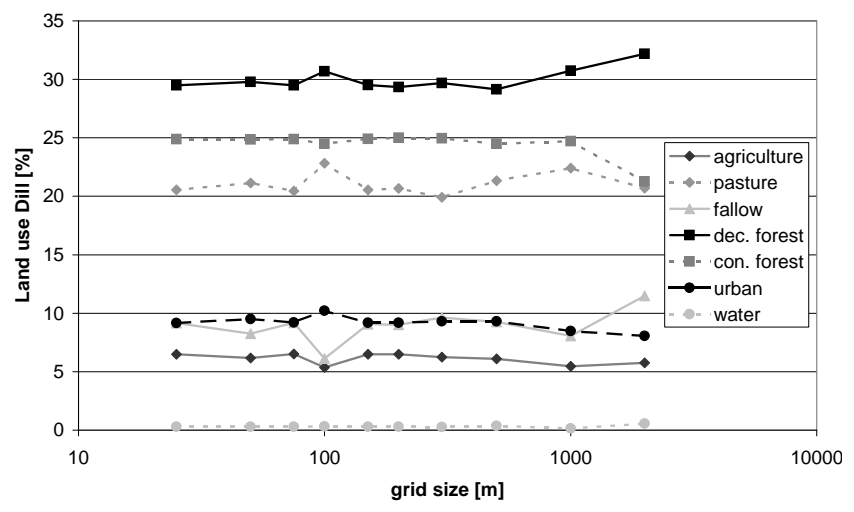

Fig. 10. Grid size dependent fractions of land use classes of the Dill catchment.

most important information for this kind of SVAT schemes which are dominated by vertical processes such as evapotranspiration. Nevertheless also the statistics of soil physical properties and topography should not be neglected. Aiming on total stream flow often masks effects of changes in fast and slow runoff components which may counterbalance their relative effects as shown above. Similarly, both the aggregation procedure of input data itself and the model application at decreasing spatial resolution (=increasing grid size) may cause changes in the simulation results, while in total both effects counterbalance to constant simulation results.

As the dependency of simulated water fluxes on grid size shows the same systematics for all investigated different subcatchments and land use scenarios, the findings are transferable to other mesoscale catchments in humid and temperate environments. Within the investigated range of physiographic characteristics (e.g. $60-700 \mathrm{~km}^{2}$ catchment size, 700-1100 mm annual rainfall, $150-700 \mathrm{~m}$ elevation above sea level, 35-55\% forest, 25-55\% agriculture) the results are transferable to other catchments. The transferability to other model types is limited in so far, as TOPLATS focuses on vertical processes, and land use information is much more dominant than the influence of neighbouring grid cells. Other models are expected to show different sensitivities to aggregating input data, if neighbourhood relations and therefore lateral fluxes are considered in an explicit way. Therefore, the results need to be verified for models rather focusing on lateral processes which should be more sensitive to a smoothing of the topography.

Concluding, this investigation shows that high quality simulation results require high quality input data but not always highly resolved data. The calculated water balances and statistical quality measures do not get significantly worse up to spatial data resolutions which should be available in almost all developed and also in many developing countries. Therefore the focus while setting up data bases should be set to improve data quality first and then to optimise data resolution secondly. 
(a)

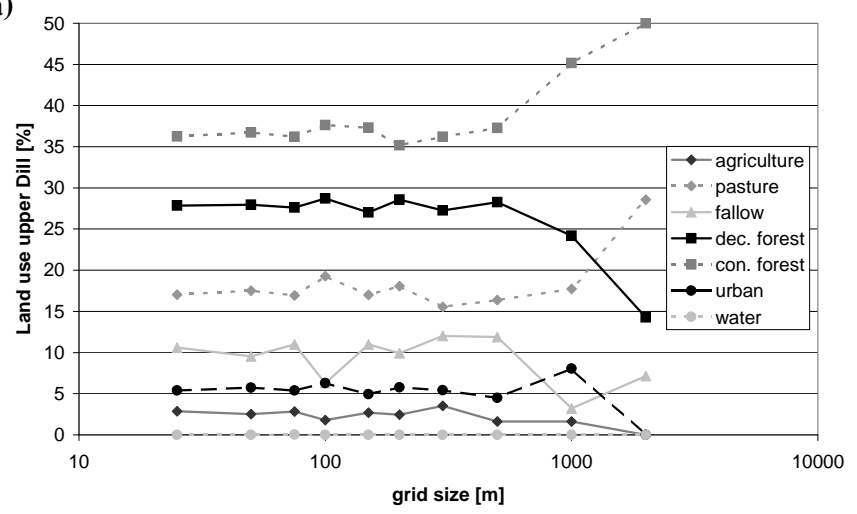

(b)

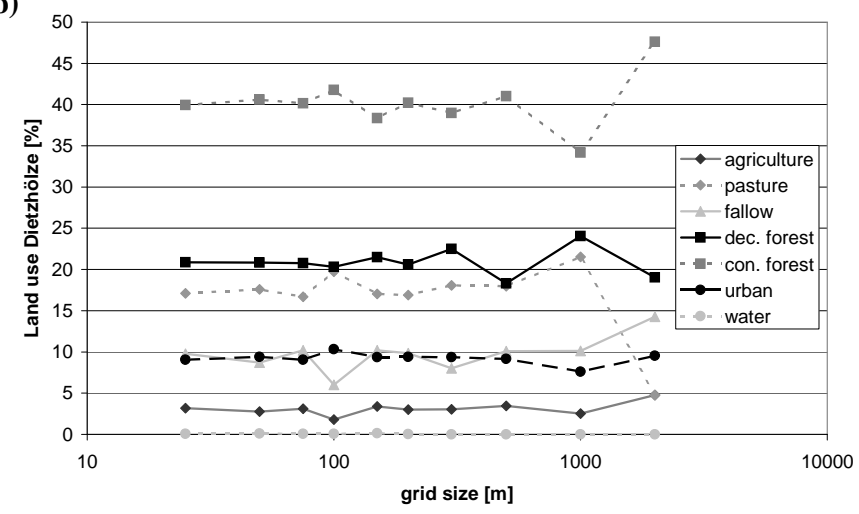

(c)

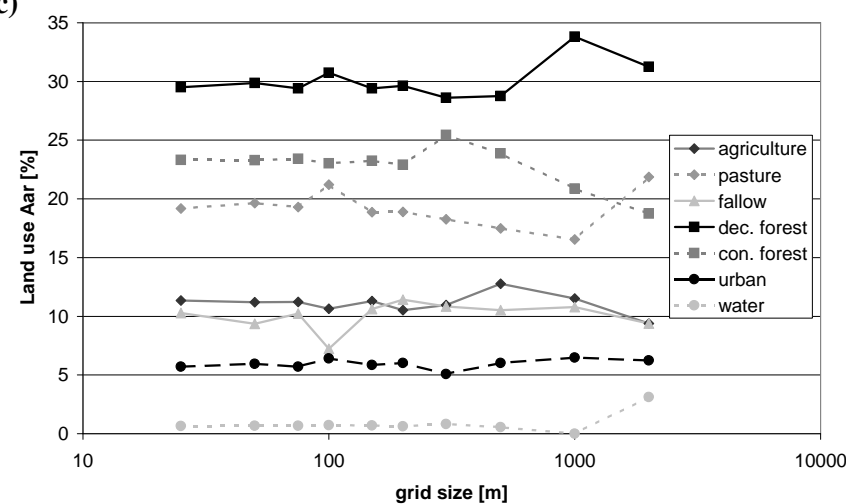

Fig. 11. Grid size dependent fractions of land use classes of the upper Dill (a), the Dietzhölze (b), and the Aar catchment (c).

Acknowledgements. The author thanks the SFB 299 of the University of Gießen for providing the data set in the framework of the LUCHEM initiative (special thanks to the organisers L. Breuer and S. Huisman) and the authors of the TOPLATS model (E. Wood and W. Crow in particular) for providing the model code and some support.

Edited by: S. Uhlenbrook

\section{References}

Andreassian, V., Perrin, C., Usart-Sanchez, I., and Lavabre, J.: Impact of imperfect rainfall knowledge on the efficiency and the parameters of watershed models, J. Hydrol., 250, 206-223, 2001.

Beven, K.: Linking parameters across scales: subgrid parameterizations and scale dependent hydrological models, in: Scale issues in hydrological modelling, edited by: Kalma, J. D. and Sivapalan, M., Advances in hydrological processes, Wiley, 263-281, 1995.

Beven, K. J., Lamb, R., Quinn, P. F., Romanowicz, R., and Freer, J.: TOPMODEL, in: Computer Models of Watershed Hydrology, edited by: Singh, V. P., Water Resources Publications, 627-668, 1995.

Booij, M. J.: Impact of climate change on river flooding assessed with different spatial model resolutions, J. Hydrol., 303, 176-
198, 2005

Bormann, H., Faß, T., Junge, B., Diekkrüger, B., Reichert, B., and Skowronek, A.: From local hydrological process analysis to regional hydrological model application in Benin: concept, results and perspectives, Phys. Chem. Earth, 30(6-7), 347-356, 2005.

Bormann, H. and Diekkrüger, B.: Possibilities and limitations of regional hydrological models applied within an environmental change study in Benin (West Africa), Phys. Chem. Earth, 28(3336), 1323-1332, 2003.

Bormann, H., Diekkrüger, B., and Renschler, C.: Regionalization concept for hydrological modelling on different scales using a physically based model: results and evaluation, Phys. Chem. Earth B, 24(7), 799-804, 1999.

Breuer, L., Eckhardt, K., and Frede, H.-G.: Plant parameter values for models in temperate climates, Ecol. Model., 169, 237-293, 2003.

Brooks, R. H. and Corey, A. T.: Hydraulic properties of porous media, in: Hydrology Paper, 3, 22-27, Colorado State University, Fort Collins, 1964.

Bruneau, P., Gascuel-Odoux, C., Robin, P., Merot, P., and Beven, K.: Sensitivity to space and time resolution of a hydrological model using digital elevation data, Hydrol. Processes, 9, 69-81, 1995.

Chen, E. and Mackay, D. S.: Effects of distribution-based parameter aggregation on spatially distributed agricultural nonpoint source pollution model, J. Hydrol., 295, 211-224, 2004. 
Crow, W. T. and Wood, E. F.: The value of coarse-scale soil moisture observations for surface energy balance modeling, J. Hydrometeorol., 3, 467-482, 2002.

Crow, W. T., Ryu, D., and Famiglietti, J. S.: Upscaling of fieldscale soil moisture measurements using distributed land surface modeling, Adv. Water Resour., 28(1), 1-5, 2005.

Endreny, T. A., Wood, E. F., and Lettenmaier, D. P.: Satellitederived elevation model accuracy: hydrological modeling requirements, Hydrol. Processes, 14(2), 177-194, 2000.

EU-WFD: EU Water Framework Directive 2000/60/EC of the European Parliament and Council, http://europa.eu.int/comm/ environment/water/water-framework/index_en.html, date of access: 1 February 2006, 2000.

Famiglietti, J. S. and Wood, E. F.: Multiscale modelling of spatially variable water and energy balance processes, Water Resour. Res., 30(11), 3061-3078, 1994a.

Famiglietti, J. S. and Wood, E. F.: Application of multiscale water and energy balance models on the tallgrass prairie, Water Resour. Res., 30(11), 3079-3093, 1994b.

Farajalla, N. and Vieux, B.: Capturing the essential variability in distributed hydrological modeling: infiltration parameters, Hydrol. Processes, 9, 55-68, 1995.

Fohrer, N., Möller, D., and Steiner, N.: An interdisciplinary modelling approach to evaluate the effects of land use change, Phys. Chem. Earth, 27, 655-662, 2002.

Gardner, W. R.: Some steady-state solutions of the unsaturated moisture flow equation with application to evaporation from a water table, Soil Sci., 85, 228-239, 1958.

Giertz, S.: Analyse der hydrologischen Prozesse in den subhumiden Tropen Westafrikas unter besonderer Berücksichtigung der Landnutzung des Aguima-Einzugsgebietes in Benin, Dissertation, Math.-Nat.-Fakultät der Universität Bonn (in German), Gemany, 2004.

HLBG: Hessische Verwaltung für Bodenmanagement und Geoinformation, Digitales Geländemodell DGM25, available at: http: //www.hkvv.hessen.de/, (date of access: 1 February 2006), 2000.

HLUG: Hessisches Landesamt für Umwelt und Geologie, Digital soil map 1:50 000, 1998.

HLUG: Hessisches Landesamt für Umwelt und Geologie, Stream gauges in the Lahn basin, http://www.hlug.de/medien/wasser/ pegel/pg_lahn.htm, (date of access: 1 February 2006), 2005.

Kuo, W.-L., Steenhuis, T. S., McCulloch, C. E., Mohler, C. L., Weinstein, D. A., DeGloria, S. D., and Swaney, D. P.: Effect of grid size on runoff and soil moisture for a variable-source-area hydrology model, Water Resour. Res., 35(11), 3419-3428, 1999.

Lahmer, W., Pfützner, B., and Becker, A.: Data-related Uncertainties in Meso- and Macroscale Hydrological Modelling, in: Accuracy 2000, edited by: Heuvelink, G. B. M. and Lemmens, M. J. P. M., Proceedings of the 4th international symposium on spatial accuracy assessment in natural resources and environmental sciences, Amsterdam, 389-396, 2000.

Milly, P. C. D.: An event based simulation model of moisture and energy fluxes at a bare soil surface, Water Resour. Res., 22, 1680-1692, 1986.

Monteith, J. L.: Evaporation and environment, in: Sympos. The state and movement of water in living organism, edited by: Fogy, G. T., Cambridge (Univ Press), 205-234, 1965.

Moore, I. D., Lewis, A., and Gallant, J. C.: Terrain attributes: Estimation methods and scale effects, in: Modelling change in envi- ronmental systems, edited by: Jakeman, A. J., Beck, M. B., and McAleer, M., Wiley, New York, 189-214, 1993.

Nash, J. E. and Sutcliffe, J. V.: River flow forecasting through conceptual models, part I - a discussion of principles, J. Hydrol., 10, 272-290, 1970.

Omer, R. C., Nelson, E. J., and Zundel, A. K.: Impact of varied data resolution on hydraulic modelling and floodplain delineation, J. Am. Water Resour. As., 39(2), 467-475, 2003.

Pauwels, V. R. N., Hoeben, R., Verhoest, N. E. C., De Troch, F. P., and Troch, P. A.: Improvement of TOPLATS-based discharge predictions through assimilation of ERS-based remotely sensed soil moisture values, Hydrol. Process., 16(5), 995-1013, 2002.

Pauwels, V. R. N. and Wood, E. F.: A soil-vegetation-atmosphere transfer scheme for the modeling of water and energy balance processes in high latitudes. 1. Model improvements, J. Geophys. Res., 104(D22), 27 811-27 822, 1999a.

Pauwels, V. R. N. and Wood, E. F.: A soil-vegetation-atmosphere transfer scheme for the modelling of water and energy balance processes in high latitudes. 2. Application and validation, J. Geophys. Res., 104(D22), 27 823-27 840, 1999 b.

Peters-Lidard, C. D., Zion, M. S., and Wood, E. F.: A soilvegetation-atmosphere transfer scheme for modeling spatially variable water and energy balance processes, J. Geophys. Res., 102(D4), 4303-4324, 1997.

Quinn, P., Beven, K., Chevallier, P., and Planchon, O.: The prediction of hillslope flow paths for distributed hydrological modelling using digital terrain models, Hydrol. Processes, 5, 59-79, 1991.

Rawls, W. J. and Brakensiek, D. L.: Prediction of soil water properties for hydrological modeling, in: Proceedings of the symposium watershed management in the eighties, edited by: Jones, E. and Ward, T. J., Denver, 293-299, 1985.

Seuffert, G., Gross, P., and Simmer, C.: The Influence of Hydrologic Modeling on the Predicted Local Weather: Two-Way Coupling of a Mesoscale Weather Prediction Model and a Land Surface Hydrologic Model, J. Hydrometeorol., 3(5), 505-523, 2002.

Sivapalan, M., Takeuchi, K., Franks, S. W., Gupta, V. K., Karambiri, H., Lakshmi, V. Liang, X., McDonnell, J. J., Mendiondo, E. M., O'Connell, P. E., Oki, T., Pomeroy, J. W., Schertzer, D., Uhlenbrook, S., and Zehe, E.: IAHS Decade on Predictions in Ungauged Basins (PUB), 2003-2012: Shaping an exciting future for the hydrological sciences, Hydrol. Sci. J., 48, 6, 857-880, 2003.

Sivapalan, M., Beven, K., and Wood, E. F.: On hydrologic similarity. 2. A scaled model of storm turnoff production, Water Resour. Res., 23, 2266-2278, 1987.

Skøien, J. O. and Blöschl, G.: Characteristic space scales and timescales in hydrology, Water Resour. Res., 39(10), 1304, doi:10.1029/2002WR001736, 2003.

Thieken, A., Lücke, A., Diekkrüger, B., and Richter, O.: Scaling input data by GIS for hydrological modelling, Hydrol. Processes, 13, 611-630, 1999.

Wolock, D. M. and Price, C. V.: Effects of digital elevation model map scale and data resolution on a topography based watershed model, Water Resour. Res., 30(11), 3041-3052, 1994.

Zhang, W. and Montgomery, D. R.: Digital elevation model grid size, landscape representation, and hydrologic simulations, Water Resour. Res., 30, 1019-1028, 1994. 